\title{
False Increase in Whole Blood Tacrolimus Levels due to Interference in an Antibody-Conjugated Magnetic Immunoassay Method
}

Kyong-Ho Cha, JeongJoong Lee, Han-Na Kim, Hyojin Chae, and Yonggoo Kim

Department of Laboratory Medicine, Seoul St. Mary's Hospital, The Catholic University of Korea College of Medicine, Seoul, Korea

Corresponding author: Yonggoo Kim

Department of Laboratory Medicine, Seoul St. Mary's Hospital, 222 Banpo-daero, Seocho-gu, Seoul 06591, Korea Tel: $+82-2-2258-1642$

Fax: +82-2-2258-1719

E-mail: yonggoo@catholic.ac.kr
Tacrolimus is an immunosuppressive agent used to prevent post-transplantation rejection. Tacrolimus has a narrow therapeutic window and therefore, its whole blood concentration is measured for therapeutic drug monitoring. In this report, we present two cases of falsely elevated tacrolimus concentrations identified in recipients of solid organ transplants due to analytical interferences in the antibody-conjugated magnetic immunoassay (ACMIA) method used. Tacrolimus concentrations measured using ACMIA were 4- to 8-fold higher than the values obtained using liquid-chromatography-tandem mass spectrometry (LCMS/MS) or chemiluminescent micro-particle immunoassay. The cause of this interference remains unknown, but the identification of a possible false elevation of tacrolimus is of paramount importance in clinical practice. Pre-treatment of samples by ethanol extraction or using alternative methods of tacrolimus measurement such as LC-MS/MS are necessary to obtain reliable results in the event of an analytical interference.

(J Lab Med Qual Assur 2015;37:148-152)

Key Words: Tacrolimus, Immunoassay, Interference, Antibody-conjugated magnetic immunoassay

\section{서론}

Tacrolimus는 calcineurin 억제제로서 간이식, 신장이식, 골 수이식 등의 장기이식 후 거부반응을 예방하기 위해 투여되는 면역억제제이다[1,2]. Tacrolimus는 cyclosporine에 비해 10100 배 더 강력한 calcineurin 억제효능이 있다고 알려짐에 따 라 tacrolimus의 사용은 장기이식 수혜자에서 cyclosporine을 대체하며 꾸준히 증가하였고, 미국의 보고에 따르면 2001년 신장이식 환자의 $50 \%, 2004$ 년 $72 \%, 2006$ 년에는 $82 \%$ 가 투여 받은 것으로 보고되었다[3,4].
그러나 tacrolimus는 적정 치료 농도 범위가 좁고 개개인의 약동학적 다양성과 장에서의 불규칙한 흡수 등의 요인으로 의하여 혈중 약물농도 측정을 통해 적절하게 관리되어야 하 며 적정 치료 농도 범위를 초과할 경우에 신독성, 신경독성 등 의 부작용이 발생한다[5]. 따라서 적정 혈중 농도의 유지를 위 해서는 치료적 약물농도 모니터링이 필요하며, 신뢰성 높은 tacrolimus 분석법은 장기이식 후 면역억제 치료에 필수적이 다[6,7].

현재 tacrolimus 정량분석은 면역측정법을 이용한 몇 가 지의 상용화된 진단시약이 사용되고 있으며, 표준검사법 
인 질량분석법(liquid-chromatography-tandem mass spectrometry) 이용이 점차 증가하고 있다[8,9]. 2011년 College of American Pathologists 참여기관 중 $82 \%$ 가 면역 측정법을, $18 \%$ 는 질량분석법을 사용하여 tacrolimus 혈중 농 도를 측정하는 것으로 조사되었다[3].

가톨릭대학교 서울성모병원에서는 검체의 전처리과정 이 필요 없는 자동화된 면역측정법인 antibody conjugated magnetic immunoassay (ACMIA)법을 이용한 Dimension ExL (Siemens Healthcare, Erlangen, Germany) 장비와 질 량분석법을 이용한 Quattro Primer XE (Waters, Milford, $\mathrm{MA}, \mathrm{USA}$ ) 장비의 두 가지 방법으로 tacrolimus 혈중 약물 농도를 측정하고 있다. 최근 2 명의 고형장기 이식 환자에서 ACMIA법에서 간섭에 의해 야기된 tacrolimus 혈중 농도의 위 증가 사례를 경험하였기에 이를 보고하고자 한다.

\section{증례}

\section{1. 증례 1}

환자는 생후 23 개월 남아로 신생아 괴사성 장염 및 단장 증후군(short bowel syndrome)으로 2014년 5월 장 이식

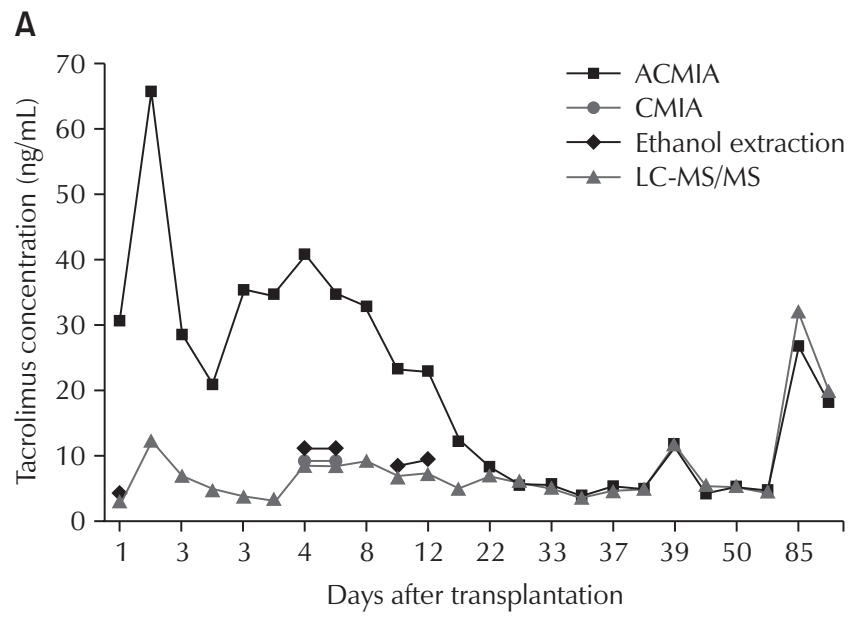

을 받았으며 면역억제 치료는 basiliximab, antithymocyte globulin, 스테로이드 및 tacrolimus 병용요법을 사용하였고, vancomycin, cotrimoxazole, meropenem, valganciclovir 등 의 약제가 병용 투여되었다. ACMIA법으로 측정한 이식 당일 에 의뢰된 검체의 tacrolimus 혈중 약물농도는 측정 가능 범 위(analytical measurement range)인 1.2-30.0 ng/mL를 초 과하였다. 검체를 영점 표준액을 이용하여 $1: 4$ 로 희석 및 혼화 한 후 재검하여 $30.6 \mathrm{ng} / \mathrm{mL}$ 의 측정결과를 얻었다. 측정결과 가 적정 치료농도 범위를 벗어나며 환자의 임상 양상과 일치하 지 않아 질량분석법으로 tacrolimus 혈중 농도를 검증한 결과 $3.0 \mathrm{ng} / \mathrm{mL}$ 로 측정되었다. 이후 10 일간 의뢰된 11 개의 연속적 인 tacrolimus 치료적 약물농도 모니터링 결과 ACMIA법에서 위 증가가 지속되었으며 이식 후 22 일째 의뢰된 검체에서는 ACMIA법과 질량분석법의 측정농도가 유사한 수준으로 회복 되었고 그 후로도 유지되었다(Fig. 1A).

ACMIA 방법에 특이적인 간섭 여부를 확인하기 위하 여 동일 검체를 면역측정법의 하나인 chemiluminescent microparticle immunoassay (CMIA) 방법으로 측정하는 타 기관에 추가분석을 의뢰하였다. 또한 혈장에 존재하는 간섭 물질 배제를 위하여 제조사에서 권장하는 확인법인 에탄올

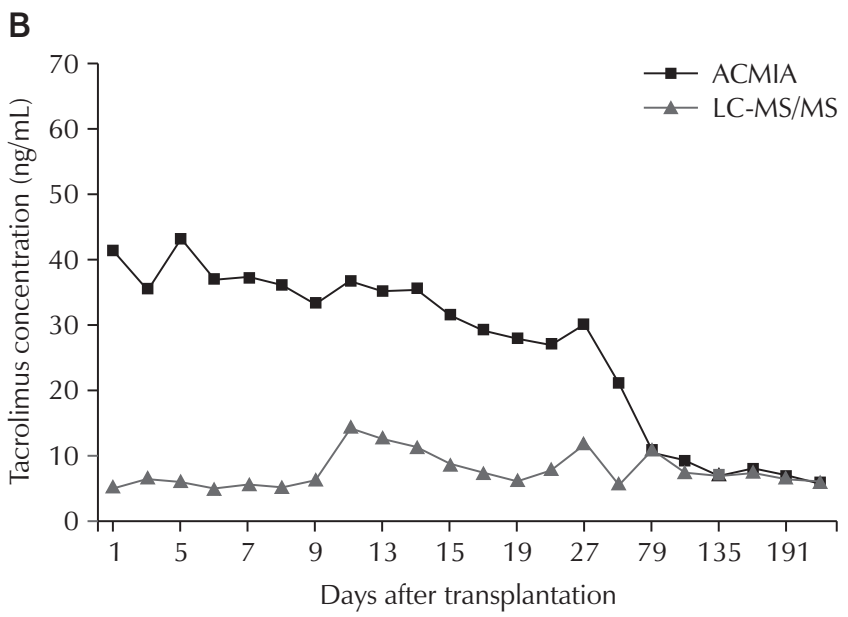

Fig. 1. Clinical course showing falsely elevated blood tacrolimus trough concentration measured using ACMIA in (A) case 1 and (B) case 2. Abbreviations: ACMIA, antibody-conjugated magnetic immunoassay; CMIA, chemiluminescent microparticle immunoassay; LC-MS/MS, high performance liquid chromatography coupled with tandem mass spectrometry.

Table 1. Confirmatory methods for false abnormally elevated blood tacrolimus trough concentration detected using ACMIA in case 1

\begin{tabular}{cccccc}
\hline $\begin{array}{c}\text { Confirmatory } \\
\text { method }\end{array}$ & $\begin{array}{c}\text { ACMIA } \\
(\mathrm{ng} / \mathrm{mL})\end{array}$ & $\begin{array}{c}\text { CMIA } \\
(\mathrm{ng} / \mathrm{mL})\end{array}$ & $\begin{array}{c}\text { LC-MS/MS } \\
(\mathrm{ng} / \mathrm{mL})\end{array}$ & $\begin{array}{c}\text { Ethanol extraction } \\
(\mathrm{ng} / \mathrm{mL})\end{array}$ & $\begin{array}{c}\text { Heterophile } \\
\text { antibody test }\end{array}$ \\
\hline Results & 40.7 & 9.0 & 8.5 & 11.0 & Negative \\
\hline
\end{tabular}

Abbreviation: ACMIA, antibody-conjugated magnetic immunoassay; CMIA, chemiluminescent microparticle immunoassay; LC-MS/MS, high performance liquid chromatography coupled with tandem mass spectrometry. 
추출법으로 전처리한 후 검체를 분석하였다. 에탄올 추출법 은 제조사의 지침에 따라 $\mathrm{EDTA}$ 전혈 검체 $300 \mu \mathrm{L}$ 와 시약등 급의 에탄올 $300 \mu \mathrm{L}$ 를 20초간 vortex 혼합하여 13,200 rpm $(16,100 \mathrm{~g})$ 에서 15 분간 원심하고 $200 \mu \mathrm{L}$ 의 상층액을 $\mathrm{ACMIA}$ 법으로 측정하여 희석배수를 곱하였다. 또한 이종친화항체 (heterophil antibody)에 의한 간섭을 평가하기 위하여 타 기 관에 이종친화항체 분석을 의뢰하였으며 이종친화항체 분석은 Infectious Mononucleosis Latex Test 키트(Pulse Scientific Inc., Burlington, Canada)를 사용하여 제조사의 지침에 따라 검사를 시행하였다.

$\mathrm{ACMIA}$ 법으로 $40.7 \mathrm{ng} / \mathrm{mL}$ 로 분석된 검체는 CMIA법, 질 량분석법 그리고 에탄올 측정법에서 각각 $9.0,8.5,11.0 \mathrm{ng} / \mathrm{mL}$ 로 측정되어 ACMIA로 측정한 결과에 비하여 현저하게 낮았 으며, 비교 방법 간에는 유사한 결과를 보였다. 이종친화항 체의 간섭을 확인하기 위한 측정에서는 음성결과를 얻었다 (Table 1).

\section{2. 증례 2}

환자는 43세의 남성으로 B형 간염으로 인한 간경화 및 식 도정맥류 등의 합병증으로 2014년 3월 간이식을 받았다. 이식 후 면역억제 치료는 basiliximab, 스테로이드, tacrolimus와 mycophenolate mofetil 병용요법을 사용하였으며, hepatitis B immunoglobulin, tenofovir 등의 약제가 함께 투여되었다.

이식 초기 tacrolimus trough 농도를 면역측정법인 ACMIA 법으로 측정하였으며 의뢰된 전혈 검체의 tacrolimus 농도가 측정 가능 범위인 1.2-30.0 ng/mL를 초과하였으므로 희석액 으로 $1: 2,1: 4$ 로 희석 검사하여 각각 $41.4 \mathrm{ng} / \mathrm{mL}$ 와 $41.6 \mathrm{ng} / \mathrm{mL}$ 의 측정결과를 얻었다. 측정결과가 적정 치료농도 범위를 벗어 나며 환자의 임상양상에서 신독성이나 약물 부작용에 해당하 는 소견이 관찰되지 않아 간섭에 의한 위 증가를 감별하기 위 해 표준법인 질량분석법으로 측정을 하였으며 질량분석법으 로 측정한 결과 $5.2 \mathrm{ng} / \mathrm{mL}$ 의 약물농도 값을 보였다. 이후 1 개 월간 15 개의 연속 검체의 tacrolimus 농도는 ACMIA법에서는 $27.0-43.2 \mathrm{ng} / \mathrm{mL}$ 로 위 증가가 지속되었으며 이식 후 32일째 의뢰된 검체에서 방법 간의 차가 감소하기 시작하여 이식 후 79일째 ACMIA법과 질량분석법의 측정농도가 유사한 수준으 로 회복되었고 유지되었다(Fig. 1B).

\section{고찰}

면역억제제 혈중 약물농도의 정량분석에 있어서 표준검사 법인 질량분석법의 도입이 점진적으로 확대되고 있으나 국내
의 면역억제제 혈중 약물농도 측정기관의 검사법 분포를 보 면 국외와 비슷하게 대부분의 기관에서 면역측정법으로 정 량분석을 시행하고 있다 $[7,10,11]$. 혈중의 tacrolimus는 8095\% 이상이 적혈구 내에 분포하기 때문에 tacrolimus 혈중 농도 측정을 위해서는 용혈과정이 필수적으로 CMIA, EMIT (enzyme multiplied immunoassay technique), 및 MEIA (microparticle enzyme immunoassay) 등의 면역측정법과 질량분석법은 수작업으로 용혈과정이 진행된다. 이에 비해 ACMIA법은 장비 내에서 시약과 초음파처리에 의해 적혈구를 용해시켜 전처리가 필요 없는 면역측정법으로 검사소요시간 및 검사실 업무량의 감소가 가능한 방법이다[12].

국외에서는 신장 및 간 이식환자에서 ACMIA법에서 tacrolimus의 위 증가를 보인 증례들이 보고된 바 있으며[8,13-19] 한 보고에 의하면 ACMIA법에 의한 tacrolimus 위 증가는 1,058 명의 환자 중 10 명의 환자에서 발견되어 전체 환자의 약 $1 \%$ 의 높은 빈도를 보였다 17$\rceil$. 최근 보고에 따르면 간섭에 의 한 tacrolimus 위 증가는 환자의 혈장 내에 존재하는 이종친화 항체, rheumatoid factor, anti-double-strand DNA 항체, 그 리고 항체-효소( $\beta$-galactosidase)와 같은 간섭요소와 시약과 의 비특이 결합에 기인한다고 한다 $[3,8,13]$.

본 증례보고에서 연구자들은 국내에서 처음으로 ACMIA법 에 의한 간섭으로 인해 tacrolimus 위 증가를 보인 증례를 보 고하였다. 증례 1 에서 용혈된 검체에서 간섭을 확인하는 에탄 올 추출법으로 검체를 전처리하여 ACMIA법으로 재측정한 결과 $11.5 \mathrm{ng} / \mathrm{mL}$ 의 측정치를 얻었고, 이는 전혈 tacrolimus 측정치인 $40.7 \mathrm{ng} / \mathrm{mL}$ 의 $70 \%$ 미만에 해당하는 값이었다. 제 조사의 지침에 따르면 에탄올 추출법으로 얻은 결과값이 전 혈 tacrolimus 농도의 $70 \%$ 미만일 경우 비특이 단백에 의 한 간섭의 가능성이 높고, 혈장에서 측정한 tacrolimus 농도 가 전혈 농도의 $30 \%$ 이상일 경우 비특이적 결합이나 간섭에 의한 영향을 배제할 수 없으므로 다른 검사법으로 측정할 것 을 권장하고 있다[20]. 혈장 내에 존재할 수 있는 비특이 단백 의 종류를 확인하기 위해 시행한 이종친화항체 검사에서 음성 결과를 얻어 이종친화항체의 간섭을 배제할 수 있었다. 또한 rheumatoid factor의 간섭을 확인한 시험에서는 참고치 이내 의 결과를 보여 간섭요인이 아님을 확인하였다. 기존의 문헌 보고에서 이종친화항체 차단관(heterophilic blocking tubes, scantibodies laboratories)과 protein $\mathrm{G}$ 레진 처리에 의해 이 종친화항체를 검출한 사례[13]가 있었으나 본 증례에서는 잔 존 검체량의 부족으로 확인하지 못하였다.

연구자들은 두 증례에서 투여된 약물과 약물의 특성으로 인 한 간섭을 확인하기 위한 약물투여 기록 조사에서 두 증례의 


\section{Journal of LABORATORY MEDICINE and QUALITY ASSURANCE}

Kyong-Ho Cha et al • False Increase Tacrolimus by ACMIA

의미 있는 공통점 또는 차이점은 발견하지 못하였다. 비록 본 연구자들은 ACMIA법에서 tacrolimus의 위 증가 원인을 명확 히 밝혀내지는 못하였으나, 환자의 임상양상과 일치하지 않는 결과가 발생하였을 때 신속히 대체방법으로 확인할 것을 제안 하고자 한다.

결론적으로 ACMIA법에서 측정한 tacrolimus 농도의 위 증 가가 의심되는 경우에는 혈장 농도 측정이나 에탄올 추출법 등 으로 간섭의 가능성을 확인하고, 간섭이 의심되는 경우에는 전 처리를 수행하는 다른 면역측정법이나 표준법인 질량분석법 으로 분석할 것을 권장한다[14,19].

\section{감사의 글}

본 연구에 도움을 주신 지멘스 헬스케어 진단사업부에 감사 를 표한다.

\section{REFERENCES}

1. Porayko MK, Gonwa TA, Klintmalm GB, Wiesner RH. Comparing nephrotoxicity of FK 506 and cyclosporine regimens after liver transplantation: preliminary results from US Multicenter trial. U.S. Multicenter Liver Study Group. Transplant Proc 1995;27:1114-6.

2. Laskow DA, Vincenti F, Neylan J, Mendez R, Matas A. Phase II FK 506 multicenter concentration control study: one-year follow-up. Transplant Proc 1995;27:809-11.

3. Parikh BA, Siedlecki AM, Scott MG. Specificity of a circulating antibody that interferes with a widely used tacrolimus immunoassay. Ther Drug Monit 2010;32:22831.

4. Meier-Kriesche HU, Li S, Gruessner RW, Fung JJ, Bustami RT, Barr ML, et al. Immunosuppression: evolution in practice and trends, 1994-2004. Am J Transplant 2006;6(5 Pt 2):1111-31.

5. Fung JJ, Alessiani M, Abu-Elmagd K, Todo S, Shapiro R, Tzakis A, et al. Adverse effects associated with the use of FK 506. Transplant Proc 1991;23:3105-8.

6. Holt DW, Armstrong VW, Griesmacher A, Morris RG, Napoli KL, Shaw LM, et al. International Federation of Clinical Chemistry/International Association of Therapeutic Drug Monitoring and Clinical Toxicology working group on immunosuppressive drug monitoring.
Ther Drug Monit 2002;24:59-67.

7. Wallemacq P, Armstrong VW, Brunet M, Haufroid V, Holt DW, Johnston A, et al. Opportunities to optimize tacrolimus therapy in solid organ transplantation: report of the European consensus conference. Ther Drug Monit 2009;31:139-52.

8. Rostaing L, Cointault O, Marquet P, Josse AG, Lavit M, Saint-Marcoux F, et al. Falsely elevated whole-blood tacrolimus concentrations in a kidney-transplant patient: potential hazards. Transpl Int 2010;23:227-30.

9. Wallemacq PE. Therapeutic monitoring of immunosuppressant drugs: where are we? Clin Chem Lab Med 2004;42:1204-11.

10. Analytical Services International. International proficiency testing scheme: tacrolimus 401 results. http:// www.bioanalytics.co.uk/Tacrolimus\%20Front\%20Pages/ tacro239.pdf (Accessed April 10, 2015).

11. Jeong TD, Gu GG, Chun S, Kim JH; Therapeutic Drug Monitoring Subcommittee, The Korean Association of Quality Assurance for Clinical Laboratory. Annual report on the external quality assessment of therapeutic drug monitoring and testing for drugs of abuse in Korea (2013). J Lab Med Qual Assur 2014;36:12-22.

12. Chung JW, An D, Song J, Chung HJ, Park HI, Lee W, et al. Performance evaluation of affinity column mediated immunometric assay for tacrolimus. Korean J Lab Med 2009;29:415-22.

13. Altinier S, Varagnolo M, Zaninotto M, Boccagni P, Plebani M. Heterophilic antibody interference in a nonendogenous molecule assay: an apparent elevation in the tacrolimus concentration. Clin Chim Acta 2009; 402:193-5.

14. Barau C, Frangie C, Goujard C, Tribut O, Parant F, Taburet AM, et al. Falsely elevated whole blood tacrolimus concentrations due to interference in an affinity columnmediated immunoassay method on Xpand dimension. Ther Drug Monit 2009;31:267-8.

15. Abei M, Yagi M, Watanabe T, Sugimoto K, Tanno Y, Kaito K. Nonspecific reacting materials that interferes tacrolimus assay by ACMIA. Rinsho Byori 2013;61:983-8.

16. Taguchi K, Ohmura T, Ohya Y, Horio M, Furukawa K, Jono $\mathrm{H}$, et al. False tacrolimus concentrations measured 


\section{Journal of LABORATORY MEDICINE and QUALITY ASSURANCE}

Kyong-Ho Cha et al • False Increase Tacrolimus by ACMIA

by antibody-conjugated magnetic immunoassay in liver transplant patient: 2 case reports and literature review. Exp Clin Transplant 2014;12:474-8.

17. Moscato D, Nonnato A, Adamo R, Vancheri M, Caropreso A. Therapeutic monitoring of tacrolimus: aberrant results by an immunoassay with automated pretreatment. Clin Chim Acta 2010;411:77-80.

18. Yamaoka M, Kawamura R, Shioda Y, Ogawa N, Koyama I, Saitoh T, et al. Analysis of the plasma concentration of tacrolimus: a useful method for distinguishing falsely elevated tacrolimus concentrations reported by the
ACMIA. Rinsho Byori 2010;58:1188-92.

19. Toraishi T, Takeuchi H, Nakamura Y, Konno O, Yokoyama T, Iwamoto H, et al. Falsely abnormally elevated blood trough concentration of tacrolimus measured by antibody-conjugated magnetic immunoassay in a renal transplant recipient: a case report. Transplant Proc 2012; 44:134-6.

20. Siemens Healthcare Diagnostics. Global product support procedures manual: procedure for troubleshooting TACR NSB samples: GLSLS-F-007-1 DCM Rev. 6.0 Effective. Deerfield (IL): Siemens Healthcare Diagnostics, 2008.

\section{Antibody Conjugated Magnetic Immunoassay법을 이용한 Tacrolimus 농도분석에서 간섭으로 인한 위 증가 2예 차경호 • 이정중 - 김한나 - 채효진 - 김용구 \\ 가톨릭대학교 의과대학 서울성모병원 진단검사의학교실}

Tacrolimus는 이식 후 거부반응을 예방하기 위해 투약되는 면역억제제이며, 좁은 치료 적정 농도 범위를 갖는 특성 때문에 전혈에서의 tacrolimus 약물 농도의 측정은 치료적 약물 농도 모니터링 에 사용된다. 저자는 고형 장기 이식 환자에서 antibody-conjugated magnetic immunoassay (ACMIA)법의 간섭으로 인해 tacrolimus 위 증가가 발생한 사례 2예를 보고하고자 한다. 사례 에서 ACMIA법으로 측정한 tacrolimus의 약물농도는 질량분석법 혹은 chemiluminescent microparticle immunoassay법으로 측정한 결과보다 4-8배 증가된 수치를 보였다. 본 증례에서 간 섭의 정확한 원인은 규명되지 않았으나, tacrolimus 위 증가를 인식하고 정확한 결과를 제공하는 것 은 임상적으로 매우 중요하며, 에탄올 추출법과 같은 검체의 전처리과정의 추가나 질량분석법과 같은 대체검사법으로 tacrolimus 혈중 농도를 확인하는 것이 특정 검사법의 간섭으로 인한 위 증가가 발생 하였을 때 tacrolimus의 정확한 혈중 농도를 얻기 위해 필수적이다.

(J Lab Med Qual Assur 2015;37:148-152) 